\title{
Effect of inclusion of Myristica fragrans on methane production, rumen fermentation parameters and methanogens population
}

\author{
S K Sirohi, P P Chaudhary, Navneet Goel \\ Nutrition Biotechnology Lab, \\ Animal Biotechnology Centre, National Dairy Research Institute, Karnal-132001, India \\ Corresponding author: S K Sirohi, email: sirohisk@gmail.com \\ Received: 18-10-2011, Accepted: 25-11-2011, Published Online: 10-03-2012 \\ doi: $10.5455 /$ vetworld.2012.335-340
}

\begin{abstract}
Aim: The present study was done to evaluate the effect of Myristica fragrans fruit active compounds addition on methane production in vitro.

Materials and Methods: Methanolic extract of Myristica fragrans fruit powder was prepared and checked for its inhibitory action on methane production in diet containing roughage 50 percent and concentrate 50 percent respectively. Methane production was estimated by Gas Chromatography.

Results: It has been shown that supplementation of Myristica fragrans reduces the methane production up to 48 percent as compared to control diet without supplementation of Myristica fragrans. Similarly real time quantification of mcr-A gene also shown the significant $(\mathrm{P} \leq 0.05)$ reduction in the number of methanogens. Myristica fragrans appeared to reduce methane production by inhibiting methanogens directly. However, digestibility of dry matter also decreased due to myristica fragrans supplementation in total mixed diet, which may affect the production of volatile acid production.

Conclusion: The active compounds extracted in methanol of Myristica fragrans emerged out to be a useful natural plant source for the inhibition of methanogenesis and its supplementation in animal feed may proves to be an effective measure to control methane emission from ruminants.
\end{abstract}

Key words: Methanogen, Methane, Mitigation, Myristica fragrans, Real Time PCR

To cite this article: Sirohi SK, Chaudhary PP, Navneet Goel (2012). Effect of inclusion of Myristica fragrans on methane production, rumen fermentation parameters and methanogens population, Vet. World, 5(6):335-340, doi: $10.5455 /$ vetworld.2012.335-340

\section{I ntroduction}

In India, methane emission from Agricultural sector, the livestock is the major contributor to the global warming. In 2009 India livestock methaneemission was 11.75 million metric tons per year higher than the 9 million metric tons estimated in 1994 [1]. To mitigate methane emission is considered as an international goal in order to reduce global warming as methane is considered to be a potent green house gas. Level of methane emission from the ruminants is affected by a number of factors such as level of feed intake, addition of lipids and ionophores in their diet, change in rumen microbial environment and the level of animal productivity have been identified [2,3,4]. Plants having secondary metabolites have been thought to play an important role in reducing methanogenesis in rumen [5]. Saponins or saponinlike substances have been reported to suppress methane production, reduce rumen protozoa counts, and modulate fermentation pattern $[6,7,8]$. Now with the advancement of molecular biological approaches it is easy to quantify the number of methanogens without practicing the tedious methods of culturing methanogens in different samples. $m c r-A$ gene is ubiquitously present in all methanogens, so it is used as a standard to quantify the methanogens under different treatments and diet conditions [9].

In the present paper an effort has been made to study the anti-methanogenic potential of Myristica fragrans (Jaiphal) plant extract by in vitro fermentation study, using Gas Chromatography and quantify the expression of $m c r$-A gene in treated and control samples.

\section{Materials and Methods}

Preparation of plant extracts: The Myristica fragrans (Jaiphal) fruits were obtained, crushed into small pieces and oven dried at $70^{\circ} \mathrm{C} .50 \%$ aqueous methanol was used as a solvent to prepare plant extracts. The plant material was then ground to pass through a $1 \mathrm{~mm}$ screen. A known quantity of finely 
ground sample was weighed into $250 \mathrm{ml}$ conical flask. The $50 \%$ aqueous methanol was added (1:10 dried plant to solvent) and the flask was tightly sealed and kept in a rotary shaker at $25^{\circ} \mathrm{C}$ and 120 rpm for 24 hour. After shaking the content of the flask, methanol extract of Myristica fragrans is directly filtered through Whatman no. 1 filter paper and used for further analysis.

Collection of Rumen Liquor for In-Vitro Gas Production Test: Rumen samples were obtained after manual mixing of rumen contents from three rumen fistulated adult male buffalo (Bubalus bubalis) after taking the permission from the Animal Ethics Committee of the institute. The buffalo were kept on a standard diet comprising concentrate and roughage in a ratio 50:50. Rumen liquor samples from the buffaloes were collected prior to the first morning feed. Just after collection of sample in insulated flask pre-warmed at $39^{\circ} \mathrm{C}$ taken to lab, immediately passed carbon dioxide and filtered through four layer of muslin cloth and then used for setting up of in vitro gas production test.

Preparation of diet: To evaluate the effect of myristica fragrans diet was prepared by taking roughage concentrate ratio of 50:50. The roughage part composed of wheat straw and the concentrate part composed of maize (33\%), ground nut cake(GNC) (21\%), mustard cake (12\%), wheat bran $(20 \%)$, deoiled rice bran (11\%), mineral mixture $(2 \%)$ and salt (1\%) respectively. Chemical composition of diet include $87.84 \mathrm{~g} / \mathrm{kg}$ DM of Organic matter(OM), 12.53 $\mathrm{g} / \mathrm{kg} \mathrm{DM}$ of Crude protein(CP) and $32.95 \mathrm{~g} / \mathrm{kg}$ DM of Acid Detergent Fibre (ADF).

Estimation of Methane Production by Gas Chromatography: For estimating the methane production incubations were carried out in $100 \mathrm{ml}$ calibrated glass syringes by previous developed method [10]. The syringes were incubated in water bath at $39 \pm 0.5^{\circ} \mathrm{C}$ [11]. The $200 \mathrm{mg}$ substrate was weighed and placed into the bottom of the glass syringes without sticking to the sides. $2 \mathrm{ml}$ of plant extract was injected before incubation. The syringes were kept in an incubator at $39 \pm 0.5^{\circ} \mathrm{C}$. The medium mixture solution was prepared by mixing $500 \mathrm{ml}$ distilled water, $0.125 \mathrm{ml}$ micro mineral, $250 \mathrm{ml}$ buffer , $250 \mathrm{ml}$ macro mineral , 1.25 $\mathrm{ml}$ resazurine and $50 \mathrm{ml}$ reducing solution (prepared fresh and added prior to incubation). Once the medium mixture solution becomes colorless, the required amount of filtered rumen liquor was added. The proportion of medium mixture solution to rumen liquor was 2:1. Just after mixing the medium and rumen liquor, $30 \mathrm{ml}$ of incubation medium was injected to the syringes using auto dispenser. The syringes were shaken gently and residual air or air bubbles if any was removed and outlet was closed. The level of piston was recorded and syringes were placed in water bath maintained at $39 \pm 0.5^{\circ} \mathrm{C}$. The syringes were shaken every one hour up to 10 hour of incubation. These trials were conducted along with respective blank and control in triplicate. After 24 hour of incubation, volume of gas was withdrawn from the tip of the incubation syringe using Hamilton gas tight syringe and analyzed for methane with the help of gas chromatograph (Nucon 5700, India) Flame ionizing detector (FID) is used. The temperature of injection port, column and detector was $40^{\circ} \mathrm{C}, 50^{\circ} \mathrm{C}$ and $50^{\circ} \mathrm{C}$ respectively. Volume of gas taken for injecting was $200 \mu \mathrm{l}$. The flow rate of carrier gas $\left(\mathrm{N}_{2}\right)$ through the column was $30 \mathrm{ml} / \mathrm{min}$ and $\mathrm{H}_{2}$ was $30 \mathrm{ml} / \mathrm{min}$ and air was $300 \mathrm{ml} / \mathrm{min}$. The standard gas for methane estimation (Spantech caliberation gas, Surrey, England) was composed of 50\% methane and 50\% $\mathrm{CO}_{2}$. The peak of methane gas was identified on the basis of retention time of standard methane gas and the response factor obtained was used to calculate methane percentage in the gas sample. The methane produced from substrate during 24 hour incubation was compared for the blank values. The volume of methane produced was calculated as follows:

Methane production $(\mathrm{ml})=$ Total gas produced $(\mathrm{ml}) \quad \mathrm{x} \%$ methane in the sample.

Estimation of ammonia nitrogen: The supernatant of each syringe including that of blank was used for $\mathrm{NH}_{3}-\mathrm{N}$ estimation. Supernatant $(5 \mathrm{ml})$ was mixed with $1 \mathrm{~N} \mathrm{NaOH}(2 \mathrm{ml})$ and steam passed on this using KEL PLUS - N analyzer (Pelican, India) and the $\mathrm{NH}_{3}$ evolved was collected in boric acid solution having mixed indicator and titrated against $\mathrm{N} / 100 \mathrm{H}_{2} \mathrm{SO}_{4}$.

Total volatile fatty acid (TVFA) estimation: TVFA concentration $(\mathrm{mmol} / 100 \mathrm{ml})$ in the supernatant was estimated according to prescribed method [12].

I ndividual volatile fatty acid ( I VFA) estimation: At the end of incubation (24h) $1 \mathrm{ml}$ of the supernatant was treated with $25 \%$ meta-phosphoric acid $(4 \mathrm{ml})$ and kept for 3-4 h at ambient temperature [13]. Thereafter, it was centrifuged at $3000 \mathrm{rpm}$ for 10 minutes and clear supernatant was collected and stored at $-20{ }^{\circ} \mathrm{C}$ until analyzed. IVFA estimated using gas chromatograph (Nucon 5700, India) equipped with flame ionization detector (FID) and stainless steel column (length 4'; o.d 1/4"; i.d $3 \mathrm{~mm}$ ) packed with Chromosorb 101. Temperature of injection port, column and detector 
was set at 200,180 and $210^{\circ} \mathrm{C}$, respectively. The flow rate of carrier gas $\left(\mathrm{N}_{2}\right)$ through the column was $40 \mathrm{ml} /$ $\mathrm{min}$, and the flow rate of hydrogen and air through FID was 30 and $300 \mathrm{ml} / \mathrm{min}$. respectively. Sample $(2 \mu \mathrm{l})$ was injected through the injection port using Hamilton syringe $(10 \mu 1)$. Individual VFAs of the samples were identified on the basis of their retention time and their concentration ( $\mathrm{mmol}$ ) and calculated by comparing the retention time as well as the peak area of standards after deducting the corresponding blank values.

Protozoa counting: For protozoal count one milliliter of the fermentation fluid was diluted with 1 $\mathrm{ml}$ of formalin ( $18.5 \%$ formaldehyde) and 3-4 drops of brilliant green and then incubated for 24 hours at room temperature. The stained protozoa were diluted (if needed) and counted by haemocytometer as per method [14].

I n vitro true DM degradability: True DM degradability of feed sample of each syringe containing residues after incubation was estimated as per method [15].

Proximate analyses and cell wall constituents: The proximate analysis of substrate was carried out as per the methods of [16]. The cell wall constituents of substrates were determined according to suggested method [15].

DNA extraction: Total genomic DNA was isolated from rumen liquor sample after methane measurement using Bacterial genomic DNA isolation kit (Chromas Biotech Pvt. Ltd., Bangalore, INDIA). For rumen samples a $1.5 \mathrm{ml}$ aliquot was taken from the rumen sample after methane measurement using a wide bore pipette so as to ensure a homogenous sample containing fluid and digesta. This was centrifuged at $12000 \mathrm{~g}$ for $5 \mathrm{~min}$ and the supernatant was removed before DNA extraction.

Conventional PCR: PCR amplification was conducted with an My Cycler ${ }^{\mathrm{TM}}$ Thermal Cycler (BioRad, USA). The reaction mixture was treated according to the following protocol: $95^{\circ} \mathrm{C}$ for $5 \mathrm{~min}$, followed by 40 cycles consisting of $95^{\circ} \mathrm{C}$ for $30 \mathrm{sec}$, $60^{\circ} \mathrm{C}$ for $30 \mathrm{sec}, 72^{\circ} \mathrm{C}$ for $1 \mathrm{~min}$, and a final extension period of $72^{\circ} \mathrm{C}$ for $10 \mathrm{~min}$.

Relative Real Time PCR: Total Genomic DNA isolated from both the sets i.e Diet+R.L.+Plant extract and Diet+R.L. (Control) was subjected to real time analysis. Both the samples were taken in triplicate. Real-time PCR assays for the quantification of methanogens, was performed $[17,18]$. The primer sets for detection and enumeration of methanogens was used [18] and the specific amplified target region was cloned by using Stratagene Blunt End Cloning kit (Stratagene,USA) in order to establish a quantitative assay. With the use of the Fermentas Plasmid Purification Kit (Fermentas,USA), plasmid DNA was isolated and the purified plasmids were quantified by spectrophotometry with multiple dilutions. The target DNA used for these experiments possessed an A260/A280 ratio greater than 1.8. The target DNA was quantified by using serial 10 -fold dilutions from $10^{1}$ to $10^{6}$ plasmid copies of the previously quantified plasmid standards. Real-time PCR amplification and detection were performed in a MiniOpticon ${ }^{\mathrm{TM}}$ Real Time PCR system (BioRad,USA) under similar conditions as were standardized during conventional PCR. In brief, SYBR Green qPCR Mastermix (2X) (Fermentas ,USA) was used for PCR amplification. Samples were assayed in triplicate in a $25 \mu 1$ reaction mixture contained $12.5 \mu \mathrm{l}$ of $2 \mathrm{X}$ Mastermix (including FastStart enzyme, FastStart Taq DNA polymerase, reaction buffer, dNTP mixture, $\mathrm{MgCl} 2$, and SYBR Green dye), $50 \mathrm{ng}$ of template DNA, and $0.5 \mu \mathrm{m}$ of each primer. All PCRs were performed in triplicate.

Statistical analysis: Experimental data of different parameters were analyzed in paired $\mathrm{T}$ test with three replicates [19].

\section{Results and Discussion}

Methane measurement by Gas Chromatography and other nutritional parameters: Chemical composition of diet presented in table 1 . After 24 hours of in vitro experimentation methane was measured out of the total gas produced in the tubes. Methane production in the control tubes was found out to be $20.47 \mathrm{ml} / \mathrm{gm}$ of diet where as in the tubes in which Myristica fragrans (Jaiphal) is supplemented methane production was significantly $(\mathrm{P} \leq 0.05)$ reduced to $12.70 \mathrm{ml} / \mathrm{gm}$ of diet. Myristica fragrans (Jaiphal) also decreased the ratio of acetate to propionate from 3.90 to 3.74 .

Table-1. Chemical composition of total mixed ration ( $50 \%$ Roughage : $50 \%$ Concentrate)

\begin{tabular}{ll}
\hline Parameter & Diet (50R:50C) \\
\hline OM & 87.84 \\
CP & 12.53 \\
EE & 3.04 \\
NDF & 60.45 \\
ADF & 32.95 \\
HC & 27.50 \\
Cellulose & 21.80 \\
ADL & 5.06 \\
TA & 12.16 \\
\hline
\end{tabular}


$\mathrm{OM}=$ Organic matter, $\mathrm{CP}=$ crude protein, $\mathrm{EE}=$ Ether extract, $\mathrm{NDF}=$ Neutral detergent fibre, $\mathrm{ADF}=\mathrm{Acid}$ detergent fibre, $\mathrm{HC}$ $=$ Hemi cellulose, $\mathrm{ADL}=$ Acid detergent lignin, $\mathrm{TA}=$ Total ash

However, IVDMD was also decreased significantly due to addition of methanolic extract of Myristica fragrans (Jaiphal) which also affect the overall production of individual volatile fatty acid production. The reduction in the methane gas production was also supported by other nutritional parameters given in Table 2. A large number of plant extracts and spices were evaluated earlier for their anti-methanogenic activity. Nature, activity and concentration of the active components reflect what type of effect a particular plant species is on methanogenesis [20]. Current study gives us knowledge about the antimethanogenic activity of a new plant extract Myristica fragrans (Jaiphal). Supplementation of Myristica fragrans (Jaiphal) was observed to elicit a rapid reduction in methane release from the rumen liquor during in vitro experimentation with a reduction of $62.04 \%$ within $24 \mathrm{~h}$ of supplementation compared with the control at the same time point.

Table-2. Dry matter digestibility and rumen fermentation parameters in control and treatment diet supplemented with Myristica fragrans

\begin{tabular}{lcc}
\hline Parameters & Control Diet & $\begin{array}{c}\text { Myristica fragrans } \\
\text { supplemented diet }\end{array}$ \\
\hline $\mathrm{pH}$ & 6.93 & 7.05 \\
$\mathrm{DDM}(\mathrm{mg})$ & $130^{\mathrm{a}}$ & $103.33^{\mathrm{b}}$ \\
Methane $(\mathrm{ml} / \mathrm{gDM})$ & $20.47^{\mathrm{a}}$ & $12.70^{\mathrm{b}}$ \\
$\mathrm{NH}-\mathrm{N}(\mathrm{mg} / 100 \mathrm{ml})$ & 4.29 & 4.95 \\
Protozoa $\left(\mathrm{x} 10^{4} / \mathrm{ml}\right)$ & $0.8^{\mathrm{a}}$ & $0.5^{\mathrm{b}}$ \\
TVFA $(\mathrm{mM} / 100 \mathrm{ml})$ & $6.12^{\mathrm{a}}$ & $4.15^{\mathrm{b}}$ \\
Acetate $(\mathrm{mM} / 100 \mathrm{ml})$ & $4.54^{\mathrm{a}}$ & $2.98^{\mathrm{b}}$ \\
Propionate $(\mathrm{mM} / 100 \mathrm{ml})$ & $1.16^{\mathrm{a}}$ & $0.79^{\mathrm{a}}$ \\
Butyrate $(\mathrm{mM} / 100 \mathrm{ml})$ & 0.41 & 0.37 \\
A/P Ratio & 3.90 & 3.74 \\
\hline
\end{tabular}

DDM = Digestible Dry Matter, $\mathrm{NH}_{3}-\mathrm{N}=$ Ammonia nitrogen, TVFA $=$ Total volatile fatty acid, $\mathrm{A} / \mathrm{P}=$ Acetate to propionate ratio

Quantitative Real Time PCR analysis: Total DNA isolated from both the treated as well as control samples were subjected to Real Time PCR analysis to monitor the quantity of methanogens in both the samples with the help of $m c r$-A gene targeting primers [18]. All the samples were taken in triplicate. The starting concentration of DNA for Real Time PCR assay was $50 \mathrm{ng}$ and other conditions for Real Time PCR were optimized. The mean $\mathrm{Ct}$ value for the treated sample was 24.08 where as that of control was 22.54 (Figure-1). The copy number of methanogens was calculated on the basis of standards in control diet and treatment (Table 3 ). The percentage decrease in the methanogens is calculated in comparison to control according to the decrease in copy number of methanogens present in treatment combination. The result shows that there is significant $(\mathrm{P}<0.05)$ decrease in the methanogens population in the treated sample as compare to that of the control which is the untreated one after 24 hour incubation.

Table-3. Copy number of methanogens calculated on the basis mcr-A gene quantification in diet supplemented with Myristica fragrans

\begin{tabular}{lll}
\hline Parameters & Control Diet $\begin{array}{c}\text { Diet supplemented } \\
\text { with Myristica fragrans }\end{array}$ \\
\hline Threshold cycle $(\mathrm{Ct})$ mean values & 22.54 & 24.08 \\
Copy Number $\times 10^{6}$ (per 50ng DNA) & $8.04^{\mathrm{a}}$ & $7.53^{\mathrm{b}}$ \\
\hline
\end{tabular}

Different superscript in row significantly different at $P \leq 0.05$

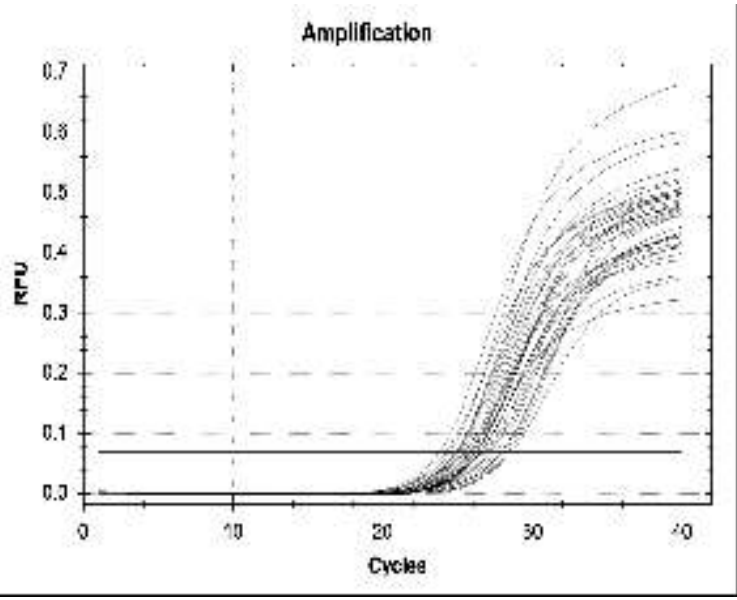

Figure-1. Differential amplification of rumen bacterial DNA templates with mcr-A gene specific primers as discussed in material methods.

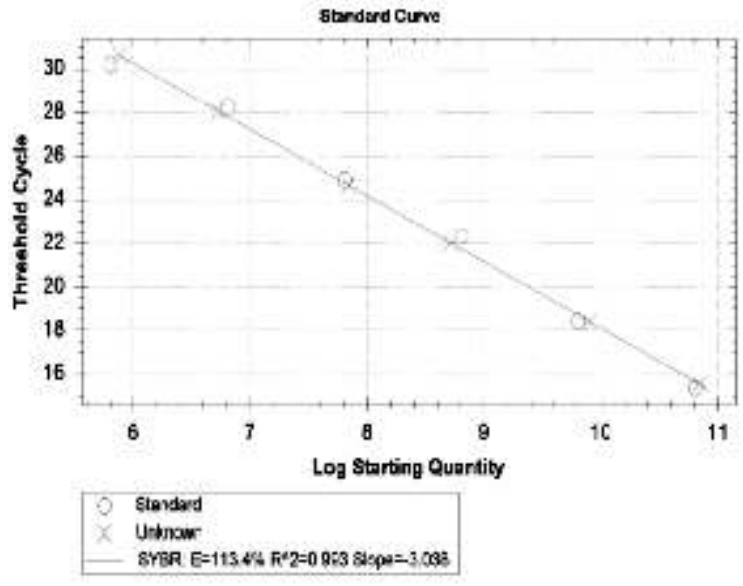

Figure-2. Standard curve obtained by plotting the logarithm of mcr-A gene concentration versus threshold cycle (Ct) mean values. The curve was constructed using data from all the six triplicate standards' amplifications 
Dissociation curve analysis for the mcr-A gene specific primer set produced a dissociation curve with two peaks at $81^{\circ} \mathrm{C}$ and $85^{\circ} \mathrm{C}$ in both the treated as well as control sample. Amplification plot, Melting curve and standard curve is presented in figure 1 and 2 respectively. Methanogens are responsible for the production of methane in the ruminants which majorly contributes to global warming. Gas chromatography and real time are rapid molecular techniques ideally suited for the checking methane produced in vitro and quantification of methanogens respectively. The number of protozoa is significantly affected in both the control and treated diets which are closely associated with methanogens. Myristica fragrans (Jaiphal) might be reducing the methane emission by inhibiting methanogen population directly and / or also the methanogen associated with protozoa. Most of the studies till date give us knowledge about the plant extracts which will inhibit protozoa population and hence decreasing the methane gas production [21].

\section{Conclusions}

This paper introduces a new plant extract which has anti-methanogenic potential without affecting the major nutritional parameters. However detailed study about the active compounds present in the Myristica fragrans (Jaiphal), dosages and mechanism of its inhibitory action on methanogens is required.

\section{Acknowledgements}

Authors are thankful to National Fund for Basic and Strategic Research in Agriculture (NFBSRA), Indian Council of Agricultural Research(ICAR),New Delhi to provide the financial support under grant $\mathrm{F}$. No. NFBSRA/PCN/AP-10/2006-07 to carry out the research work. Senior Research Fellowship provided by the same funding agency to PPC and NG is also fully acknowledged.

\section{Competing interests} interests.

The authors declare that they have no competing

\section{References}

1. Singh, M. (2009). Cows with Gas: India's GlobalWarming Problem. Time World.

2. Johnson, K.A. and D.E. Johnson, (1995). Methane emissions from cattle. J Anim Sci. 73:2483-2492.

3. Hironaka, R.; Mathison, G.W.; Kerrigan, B.K. and Vlach, I. (1996). The effect of pelleting of alfalfa hay on methane production and digestibility by steers. Sci Total Environ. 180,221-227.

4. McAllister, T.A.; Okine, E.K.; Mathison, G.W. and
Cheng, K.J. (1996). Dietary, environmental and microbiological aspects of methane production in ruminants. Can JAnim Sci. 76:231-243.

5. Kamra, D.N.; Patra, A.K.; Chatterjee, P.N.; Kumar, R.; Agarwal, N. and Chaudhary, L.C. (2008). Effect of plant extracts on methanogenesis and microbial profile of the rumen of buffalo: a brief overview. Animal Production Science. DOI: 10.1071/EA07268.

6. Makkar, H.P.S. and Becker, K. (1997). Degradation of Quillaja saponins by mixed culture of rumen microbes. Lett Appl Microbiol. 25:243-245.

7. Wang, Y.; McAllister, T.A.; Newbold, C.J.; Cheeke, P.R. and Cheng, K.J. (1997). Effects of Yucca extract on fermentation and degradation of saponins in the Rusitec. Proceedings of Western Section. American Society of Animal Science. 48:149-152.

8. Hristov, N.A.; McAllister, T.A.; Van Herk, F.H. Cheng, K.J.; Newbold, C.J. and Cheeke, P.R. (1999). Effect of Yucca schidigera on ruminal fermentation and nutrient digestion in heifers. J Anim Sci. 77:2554-2563.

9. Thauer, R.K. (1998). Biochemistry of methanogenesis: a tribute to Marjory Stephenson. Marjory Stephenson Prize Lecture. Microbiology. 144: $2377-$ 2406.

10. Menke, W. (1979). The estimation of the digestibility and metabolizable energy content of ruminant feeding stuffs from the gas production when they are incubated with rumen liquor in vitro. $J$. agric. Sci. 93:217-222.

11. Blümmel, M.; Ørskov, E.R. (1993). Comparison of gas production and nylon bag degradability of roughages in predicting feed intake in cattle. Anim.Feed Sci. Technol., 40:109-119.

12. Barnet, A.J.G., Reid, R.L., (1957). Studies on production of volatile fatty acids from grass by rumen liquor in artificial rumen IVFA production from fresh grass. Journal of Agriculture Science, 48, 315.

13. Erwin, E.S., Macro, G.A., Emery, E.M., 1961. Volatile fatty acid analysis of blood and rumen fluid by Gas chromatograph. Journal of Dairy Science 44, 1768-1771.

14. Dehority, Burk A., (1984). Applied and Environmental Microbiology. Vol. 48, No. 1.

15. Van Soest, P.J., Robertson, J.B., Lewis, B.A., 1991. Methods for fiber, neutral detergent fiber and nonstarch polysaccharides in relation to animal nutrition. Journal of Dairy Science 74, 3583-3597.

16. AOAC, (1995). Official Methods of Analysis.16th ed. Association of Official Analytical Chemists, Arlington,VA.

17. Denman, S.E.; McSweeney, C.S. (2006). Development of a real-time PCR assay for monitoring anaerobic fungal and cellulolytic bacterial populations within the rumen. FEMS Microbiol Ecol., 58:572-582.

18. Denman, S.E.; Tomkins, N.W. and McSweeney C.S. (2007). Quantification and diversity analysis of 
ruminal Methanogenic populations in response to the antimethanogenic compound bromochloromethane. FEMS Microbiol Ecol., 62:313-322.

19. Snedecor, G. W., W. G. Cochran, (1968). Statistical Methods, 5th ed. Iowa State Univ. Press, Ames., I.A.

20. Gonz'alez, R.G.; L'opez, S.; Fern'andez, M.; Bodas, R. and. Gonz'alez, J.S. (2008). Screening the activity of plants and spices for decreasing ruminal methane production in vitro. Anim.Feed Sci. Technol. 147: 36- 52 .

21. Guo, Y.Q.; Liu, J.X.; Lu, Y.; Zhu, W.Y.; Denman, S.E. and McSweeney, C.S. (2008). Effect of tea saponin on methanogenesis, microbial community structure and expression of mcrA gene, in cultures of rumen microorganisms. Lett. Appl. Microbiol. doi:10.1111/j.1472765X.2008.02459.x 